\title{
Truth commissions and gender: A South African case study
}

\author{
Ayumi Kusafuka
}

\section{Abstract}

South Africa's gendered past was never substantially addressed by the South African Truth and Reconciliation Commission (TRC) despite attempts by women's groups to ensure its inclusion.. The TRC's treatment of gender was in part constrained by its 'gender-blind' mandate, which ignored the different experiences and interests of men and women. Its shortfalls were further reinforced by the combination of limited time and resources, the lack of a systematic proactive gender strategy, and the lack of sustained involvement and interventions by the feminist community. While interventions by women's groups and activists led the Commission to take up gender in ad hoc ways, such as through the Special Hearings on Women, the engagement of the TRC with gender remained at best tangential and as such the opportunity to capture a more complete picture of the apartheid era was lost

* Ayumi Kusafuka has worked for human rights non-governmental organisations on gender and prosecutions issues. For the International Centre for Transitional Justice, she has worked on truth commissions and gender with a focus on East Timor and South Africa. Most recently, with the International Women's Human Rights Law Clinic of the City University of New York Law School, she has drafted an amicus curiae submission to the Inter-American Commission on Human Rights and helped draft submissions to the United Nations Committee against Torture.

The author gratefully acknowledges the comments and suggestions made by Beth Goldblatt and Kelli Muddell in working on this case study, which also benefits from her conversations (in alphabetical order) with Vanessa Barlosky, Brandon Hamber, Antjie Krog, Piers Pigou, Nicolene Rousseau, Graeme Simpson, and Christelle Terreblanche. 
South Africa's Truth and Reconciliation Commission (TRC) provides an interesting case study for analysts of transitional justice as it proved a missed opportunity for revealing the gendered nature of South Africa's past. By evaluating the Commission, it is possible to see how its ad hoc approach to gender meant that the different experiences of men and women were fundamentally overlooked during the South African process.

In 1995, the first democratically elected South African government established the Truth and Reconciliation Commission through the Promotion of National Unity and Reconciliation Act No 34. The Commission was set up to investigate 'the nature, causes and extent of gross violations of human rights' committed 'within or outside' the country during the period from March 1960 to May 1994 - between the launching of the African National Congress's (ANC) armed resistance movement and the inauguration of Nelson Mandela as the country's first democratically elected president (Fullard 2004). It was founded on the premise that truth-telling about past gross human rights violations would help facilitate 'the process of understanding our divided pasts' and that 'the public acknowledgement of 'untold suffering and injustice' helps to restore the dignity of victims and afford perpetrators the opportunity to come to terms with their own past' (TRC of SA 1998:1.4.3). The Commission placed particular emphasis on 'hearing the experiences of victims of gross violations from the people themselves' (TRC of SA 1998:5.1.6).

Controversially, as part of a political compromise reached between the apartheid government and the ANC, the TRC could grant conditional amnesty to perpetrators in return for their full disclosure of the truth (Hamber and Mofokeng 2000). For many, the functioning of the Commission was an important process in reconciling a deeply divided nation and avoiding a retributive process. The TRC was composed of three committees: the Human Rights Violations Committee (HRVC), the Amnesty Committee (AC), and the Reparation and Rehabilitation Committee (RRC). It had strong quasi-judicial investigative powers, including those of subpoena and search and seizure and 
these powers were enhanced by various measures to ensure the protection of witnesses.

While the TRC was committed to the transparency of the process, it also had powers to limit cross-examination, hold hearings in camera, close the proceedings to the public, keep the identity of witnesses from the public and from records, and provide formal protection to witnesses. The TRC's commitment to a transparent process allowed non-governmental organisations (NGOs) to monitor the Commission's work closely and participate in the TRC process from involvement in the recruitment of staff to taking statements and making recommendations for the final report (Burton 2000). The TRC hearings were open to the public and received extensive media coverage in the print and electronic media, as well as live coverage on television and radio (Hayner 2001).

Ultimately, the Commission's seven-volume report, released in October 1998 (first five volumes) and March 2003 (the last two volumes), declared apartheid a crime against humanity. In the report, a separate chapter focused on the experiences of women and reflected the fact that instead of mainstreaming gender in its entire process or having a special unit tasked exclusively to focus on gender, the South African TRC had only undertaken ad hoc measures to address gender in some aspects of its process and products.

In total, during the two years of its operation the TRC received over 21000 statements concerning nearly 38000 violations of human rights. ${ }^{1}$ The majority of these statements pertained to violations committed against men - primarily murder, attempted killing, or severe ill-treatment - and few centred on women's own experiences, particularly of sexual violence. While women accounted for 54.8 percent statements taken, women represented only 43.9 percent of those who reported their own experience of direct human rights violations (TRC of SA 1998:4.10.13). Eighty five percent of these women reported severe illtreatment they had experienced as direct victims. Of a total of 446 statements coded as sexual abuse, 40 per cent of those in which the sex of the victim was specified reported the abuse of women. Rape was mentioned in only 140 cases,

1 The Commission heard a total of 21298 statements concerning 37672 allegations of human rights violations (TRC of SA 1998:1.6.Appendix 2.para.6). 


\section{Ayumi Kusafuka}

but it is estimated that the number represents only a very small fraction of the incidents of rape that occurred in the period of the TRC's mandate (Goldblatt 2006).

The TRC held three 'special hearings' on women in Cape Town, Johannesburg and Durban in order to provide an arena for women to talk about the specific violations they had suffered (Madlala-Routledge 1997). The hearings created the opinion that the majority of the women who testified at the TRC spoke, as secondary victims, about others. Addressing the growing concern over women's tendency not to testify about their own experiences of violations, the Commission changed its statement-taking protocol to encourage women deponents to talk about themselves.

While there have been some interrogation of the gendered nature of the South African Truth Commission this article will interrogate the various stages of its work from the development of its mandate to the final report in order to map how and why gender issues were overlooked during its processes. While previous studies have tried to question the South African TRC's inadequate attempts to incorporate gender, this study will focus on how each stage of its process contributed to this shortfall in order to inform those devising future initiatives.

\section{Defining a human rights violation}

The TRC mandate's limited definition of what constituted a human rights violation ultimately contributed to gender being marginalised in the Truth Commission's process. The Act called on the TRC to investigate 'gross violations of human rights', which were defined as 'the violation of human rights through the killing, abduction, torture or severe ill-treatment of any person,' or the 'attempt, conspiracy, incitement, instigation, command or procurement to commit' such acts (Promotion of National Unity and Reconciliation Act No 34 of 1955: art. 1(1)(ix)). The TRC mandate made no specific reference to rape and other gender-based crimes but civil society lobbying resulted in the term 'severe ill-treatment' being interpreted to include a wide range of abuses, including rape and other forms of gender-based violence (Goldblatt and Meintjes 1996). 
Nonetheless, this still constituted a narrow interpretation of human rights violations, which largely excluded the wider gendered experiences of apartheid violence. Submissions by NGOs urged the TRC to investigate as 'severe illtreatment' violations of economic, social and cultural rights (Coalition of NGOs 1997). While ultimately the TRC report acknowledged that 'the policy of apartheid was itself a human rights violation', the TRC's mandate focused on 'bodily integrity rights' that had 'resulted in physical or mental harm or death and were incurred in the course of the political conflicts' of the past (TRC of SA 1998:1.4.56).

The Act did include in its definition of 'victims' the 'relatives or dependants' of those who experienced 'harm in the form of physical or mental injury, emotional suffering, pecuniary loss or a substantial impairment of human rights' due to 'gross violation of human rights' or 'an act associated with a political objective for which amnesty has been granted, or those who assisted such victims or relatives or deponents of such victims' (TRC Act Chap.1 (1) $(\operatorname{xix})(c))$. Women activists cited the definition as 'very important' because it 'locates wives, mothers, and children at the centre of "gross violation of human rights"' as 'primary, not secondary' victims (Goldblatt and Meintjes 1998b:34).

\section{Addressing gender in the Truth Commission's work}

The failings of the TRC to fully incorporate gender issues can in part be explained by the ambiguous relationship between the TRC and women's groups since neither side engaged with the other in a consistent and proactive manner. During the early days of South Africa's new democracy, women's organisations were focused on pressing gender concerns such as legal and constitutional reform, women's representation in the parliament and domestic violence. As a result, they were largely absent during the drafting process of the TRC legislation thereby excluding themselves from defining the Commission's framework. This can in part be explained by the fact that initially women's groups were divided and unsure as to how to engage with the TRC. Gender activist and lawyer Ilse Olckers recalled the dilemma that: 


\section{Ayumi Kusafuka}

many of us [women's activists and groups] had been asking each other, informally - slightly panicky - for many months, as the [TRC] process unfolded before our eyes. But nobody had the resources; and the ones who did felt they did not have a mandate; and the women's movement was silent (Olckers 1996:61).

Only after the legal framework was finalised and the TRC began its work did a small group of feminist activists begin to start lobbying to address the genderblind legislation. In March 1996, a range of representatives from women's organisations, some TRC staff, psychologists and lawyers discussed concerns over the lack of gender perspectives in the TRC's mandate and subsequently presented a submission by the University of Witwatersrand's Centre for Applied Legal Studies (CALS) to the Commission (Goldblatt and Meintjes 1996). The co-authors of the submission, Beth Goldblatt and Sheila Meintjes, analysed how men and women experienced apartheid's political violence differently due to their prescribed roles in the society. They argued that while men were usually the primary actors in the political struggle, women as wives and mothers suffered economic loss when the men in their households were detained, imprisoned or killed. The forms of physical and psychological torture used against women also differed from those tactics used against men, targeting women's femininity and sexuality. Alerting the TRC that women would likely be hesitant to speak of their own experiences of abuse, they made a set of recommendations on how the TRC could take a gender-sensitive approach.

The CALS submission did persuade the TRC to adopt more gender-sensitive strategies such as holding special women's hearings, creating gender-sensitive statement-taking protocols, conducting research on gender, and having a chapter on women in the final report. The interventions by the feminist community also succeeded in ensuring rape and other sexual violence were included in the definitions of torture and 'severe ill-treatment' (Van der Merwe et al. 1999). Further, a small 'Gender and the Truth and Reconciliation Commission' working group of individuals such as trauma counselors and psychologists from the Gender Research Project of CALS and the Centre for the Study of Violence and Reconciliation (CSVR) was formed and met every six to eight weeks during 
1996 and 1997 to discuss gender issues at the TRC and to strategise on how NGOs could intervene further, particularly in relation to a reparations policy. However, the initiative to impact the TRC to take a gender-sensitive approach lost momentum in the later stage of the TRC's life as women's groups focused on what were deemed the more burning gender concerns facing South Africa at that juncture.

\section{Does truth have a gender?}

Although the TRC was largely receptive to the recommendations of women's groups and other NGOs, it unfortunately overlooked gender concerns in its analytical frames, which created a hierarchy of human rights violence of which political violence was the primary interest. As analyst Graeme Simpson (2004:16) notes:

' $[\mathrm{P}]$ rivileging' certain acts of political violence, and seeing race, class and gender as subsidiary to party-specific political motivations, had the ironic effect of shrouding rather than illuminating them as intrinsically political and self-explanatory characteristics essential to any understanding of the dominant patterns and experiences of violence under apartheid.

Further, the TRC's focus on 'political' offences resulted in it neglecting the link between what was considered 'extraordinary' and 'ordinary' violence, and produced a missed opportunity to examine the structural, ideological and systemic background of gender relations, especially apartheid's structural abuses against women. Madeleine Fullard, former researcher for the TRC, laments that ' $t$ ] he absence of focus on apartheid's systemic rather than repressive character had grievous consequences for women' (Fullard 2004).

The TRC report itself acknowledges the implications of the Commission's restricted focus. It notes that 'The Commission's relative neglect of the effects of the "ordinary" workings of apartheid has a gender bias, as well as a racial one' and concedes that 'the definition of gross violation of human rights adopted by 


\section{Ayumi Kusafuka}

the Commission resulted in a blindness to the types of abuse predominantly experienced by women' (TRC of SA:4.10.144).

In practice, both the Amnesty Committee and the Human Rights Violations Committee (HRVC) often struggled to draw a line between political and personal motives behind sexual violence, although there was evidence that rape may have been sanctioned by the security forces or at least used with the effect of terrorising, intimidating and punishing women and their communities (Goldblatt and Meintjes 1996). The following excerpts from the interaction between the HRVC and Nozibonelo Maria Mxathule, a victim of rape, at the Special Women's Hearing in Johannesburg on 29 July 1997, demonstrates the challenge of identifying motives for the sexual abuse of women (emphasis added):

CHAIRPERSON: I will try to ask you a few questions really aimed at making sure that we get a clear picture of what you have said. Did you say you were a member of any political position [/party]? If so, did you hold any position?

MS MXATHULE: I was a member of the Youth Congress.

CHAIRPERSON: When you started off you told about an experience where a man was trying to enter the door. Can you just give a clear context of that, because the way it came it was not clear enough as to what was the reason behind that.

MS MXATHULE: This person attempted to rape me, because he had lust for me.

CHAIRPERSON: But he was not doing that in a political context, he was just doing it as a man who wanted to do that to you as a person? I am trying to get that clarity.

MS MXATHULE: Yes, because when I explained this to his father, he 


\section{Truth commissions and gender: A South African case study}

explained to my father that your child is, they are use [ sic] to each other.

CHAIRPERSON: Again, I would like us to be clear on this. So, this man wanted to rape you not because it was a, there was no political context. He was just doing it, because he is use [sic] to doing that.

MS MXATHULE: The riots were not yet over in Jubatine at that time. We were still involved in the political struggle.

MS SEROKE: [a debriefer]: Maria, we want you to assist us to have the political context of the first story you told us about. You heard that Sheila Meintjies during her submission here, she said that at some of the days, there is a very thin line between domestic violence and political violence. ... did he do this [rape] because he knew you were a Comrade or he just did it because he wanted to have sex with you?

MS MXATHULE: He did this because he knew I was a Comrade. (SOURCE: Special Hearing on Women in Johannesburg, July 29, 1997, Nozibonelo Maria Mxathule)

\section{Statement-taking}

From the outset concern was expressed that the South African TRC may not be able to solicit women's statements of their own experiences of abuses, especially sexual violations. As already noted, some women's organisations had called for changes to the method of statement-taking including requests that only women statement-takers interview female victims. By April 1997, the Commission had modified its statement-taking protocol to be more sensitive to female deponents and had also trained statement-takers to ask more 'probing questions' in order to reveal more about women's own experiences.

In general, however, the statement-taking procedure did not prove to be successful in soliciting women's statements about themselves. One criticism 


\section{Ayumi Kusafuka}

leveled is that due to time constraints statement-taking became a checklist with little space for a deponent to share her own narrative (Lars Buur 2002:78). On many occasions victims expressed disappointment at their statement-takers, who were considered as not adequately sensitised about gender-based violence to deal with victims of sexual abuses (CSVR and Khulumani Support Group 1998). Furthermore, the importance of ensuring statements from women on their own experiences was not tackled during the Commission's outreach programme (CSVR and Khulumani Support Group 1998). The Commission failed to conduct any separate outreach campaigns which specifically targeted women and instead expected them to come forward as part of the general outreach efforts (Interview with Christelle Terreblance 2005). In addition, the South African TRC did not allow for statements to be submitted after the closing of the Commission's doors in December 1997 (TRC of SA 1998:6.6.37).

As outlined above, the TRC failed to secure representative statements of women's own experiences of violence under apartheid (Motsemme 2004). On the one hand, the lack of statements on women's experiences muted women's voices, stereotyped women as secondary witnesses, and marginalised women in the TRC's discourse on the past. However, a study by South African psychologist Pumla Gobodo-Madikizela has revealed that a significant number of the women who spoke of others' experiences before the TRC, typically those of their sons, fathers and husbands, did so to commemorate those loved ones lost during the violence (Gobodo-Madikizela 2005:15). As such, she argues that these women were not undermining their own experiences, but instead viewed the Commission as a cathartic event.

\section{The Hearings}

The South African TRC held a number of thematic and sectoral hearings, including the special women's hearings, and these provided the most visible space where gender-based human rights violations were discussed. Madeleine Fullard (2004) has noted that these hearings 'constituted the TRC's only organised engagement with broader sites of apartheid abuse'. 
The women's hearings in Cape Town (August 1996), Durban (October 1996) and Johannesburg (July 1997) were arranged specifically to gather information on women's experiences of apartheid. To some degree, the hearings shifted the way in which women were seen during the TRC process and also changed the discourse on women's experiences (Krog 2005). At these hearings, women were allowed to testify in camera before a women-only panel of commissioners and a largely female audience. These special arrangements did encourage women to speak about their own abuse, which would not have been told at regular hearings. These hearings unveiled the specific gendered nature of the suffering women had experienced. The women who came forward to give testimony at these hearings revealed how they had been hiding and, according to Debrah Matshoba, 'how shattered [they] were inside' (TRC of SA 1997c). At the hearings, women spoke about their own experiences, relating to harassment, detention, imprisonment, abduction, torture, murder and rape, as well as the psychological, emotional, and financial pain of losing their loved ones. Goldblatt and Meintjes noted that 'these hearings clearly indicated that women were afraid and ashamed to speak about their experiences but when provided with an opportunity to do so in a safe environment, were more willing to come forward' (Goldblatt and Meintjes 1996:9).

The women's hearings also raised awareness of the particular difficulties women faced in publicly disclosing their experiences. According to Thenjiwe Mtintso, former chairperson of South Africa's Commission on Gender Equality, many women were 'not ready' to open their 'wounds' and make public their 'signs of the pain' (TRC of SA 1997c). At the Johannesburg hearing, Sheila Meintjes noted the importance of breaking the silence on women's experiences and encouraged women to speak out to address the problem of domestic violence. In addition to women's individual experience of violence, expert testimonies at the women's hearings highlighted broader patterns of abuse and resistance, enabling conditions, and social impact. Meintjes, among others, explained how the position of women in South African society had facilitated human rights violations against women, particularly sexual abuses (Special Hearing on Women 1997). 


\section{Ayumi Kusafuka}

In addition to the special hearings on women, some of the other sector and thematic hearings unmasked a wide range of abuse women had experienced under apartheid. The health sector hearings suggested that the rights of black women, both as doctors and as patients, were violated, especially also with regard to access to obstetrics and gynaecological care. The media hearings exposed discrimination against women, black women writers in particular, in the field of journalism (TRC of SA:4.6.53). The business sector hearings highlighted that all the discriminatory legislation and many practices of the apartheid system had severely undermined the opportunities for women, particularly black women, with regard to both employment in the business sector and financial activities, such as obtaining loans (Business Sector Hearing 1997). Bonini Jack acknowledged at the hearing that 'the Land Bank ... acknowledges a history of gender discrimination, both in terms of our treatment of women farmers and with regard to the difficulties faced by women staff' (TRC of SA 1997e). At the same hearing, Andre Jansen noted that 'the bank [Land Bank] wishes to apologise' for the 'injustices' it had committed, including having 'participated in denying equal opportunities for women and non-white people' (TRC of SA 1997e). The legal hearings addressed the lack of legal protection for victims, including victims of rape (TRC of SA 1997d) and underlined the need to transform the legal system of the country into one based on 'representivity in terms of race and gender' that would empower victims (TRC of SA 1997b).

Women also talked about their experiences at some of the sector and thematic hearings. At the prison hearings, women made testimony not only as witnesses but also as victims - detainees and prisoners. Statements revealed how women had been subject to physical and mental torture and how women's prisons did not cater for the specific needs of women, such as gynaecological services. The special hearing on children and youth showed that the mental strain caused by the political struggle had often destroyed women's family life. At the Durban special hearing on children and youth, women from KwaZulu-Natal confessed that they were too depressed and distraught by the violence to take care of their children (TRC of SA 1997a). As a result, their neglected children often chose to run away from home. 
The TRC hearings did include some testimonies on the discrimination against gays and lesbians in South Africa, and particularly the special hearings on conscription revealed the trauma suffered by many gay conscripts. The submissions to the institutional hearings on the health sector suggested that gay conscripts were subjected to 'aversion therapy' or 'electric shocks' intended to 'convert' their sexual orientation without their consent (Health and Human Rights Projects (HHRP) 1997; Van Zyl et al. 1999). However, the Commission reduced these allegations to one sentence on the aversion therapy practised on gay conscripts in its final report (TRC of SA 1998:4.5.41).

The unique environment of the special women's hearings was distinct from the individual public hearings where women's firsthand experiences were largely subsumed among wider human rights violations. Beth Goldblatt has lamented the TRC's failure to hold more localised hearings on gender, particularly in rural areas where the most harsh experiences of women's abuses could be exposed (Goldblatt 2004). The fear of public humiliation and social stigma, particularly in cases of sexual abuse, was a major deterrent for women to reveal human rights violations they had suffered. During one public hearing, Zanele Zingxondo testified about being subjected to sexual torture during interrogation, but she avoided using the word rape or making any direct reference to having electric shocks administered on her genitals (Zingxondo 1996).

Very few female perpetrators appeared before the TRC. Of the amnesty applications in which the sex of the applicant was known (4 721 applications out of a total of 7128 applications), merely fifty-six applications for amnesty (just over one percent) were known to have come from women. At the time when the first five volumes of the TRC Report were written, the AC had heard hearings of forty of the amnesty applications made by women, and made decisions in only twenty-six of the cases. Two women had been granted amnesty for having been involved in bomb planting and theft, and the others for possession and distribution of weapons (TRC of SA 1998:4.10.128).

The TRC's engagement with women ultimately suggests that the official and public processes of statement-taking and public hearings were not necessarily successful in recording and addressing a gendered history of human rights 


\section{Ayumi Kusafuka}

violations. The TRC's lack of statements on women's experiences and the fact that the most active participation of female deponents was during the Special Women's Hearings illustrates that women were much more willing to talk in public about themselves, even about the most sensitive experiences, when they were in a specific environment.

\section{The Amnesty Committee}

Section 20 of the TRC Act (Promotion of National Unity and Reconciliation Act No 34 of 1955) allowed for the granting of amnesty where an act is 'associated with a political objective committed in the course of the conflicts of the past' in return for 'a full disclosure of all the relevant facts relating to such act'. The Act thus disqualified an act committed 'for personal gain' or 'out of personal malice, ill-will or spite, directed against the victim of the acts committed'. Women's rights advocates and scholars objected to granting impunity for the perpetrators of crimes against women, particularly rape (Krog 2001), while expressing concern that rape and sexual violence would not be able to fall within the criteria of a political act as defined by the Act due to the ambiguity surrounding rape and sexual violence (Goldblatt and Meintjes 1996).

As already mentioned, the TRC's focus on physical and political violence meant the hearings of the HRVC and the AC left little room for gendered human rights abuses to be explored. Fullard (2004) observes that statements on human rights violations were 'accepted by the TRC only if they fell within the narrow interpretation of its mandate'. Filtered through the narrow lens of the Commission, as mentioned already, gendered human rights violations were at the periphery. Similarly, the AC hearings tried to curtail information on violations that were not included in amnesty applications, thereby excluding the possibility of exploring the detail of other violations, including rape. For example, at the Amnesty Committee hearing for Jabu Jacob Nyethe, when details of rapes were revealed, the Chairperson reminded those present that the hearing should limit collecting testimonial evidence on rape as there was no application for amnesty against rape (TRC of SA 1998). 
Many commissioners experienced difficulties in locating gender in the prism through which human rights violations were articulated. Ultimately, the Amnesty Committee received very few applications for amnesty for sexual violence. Those it did receive came mainly from the self-defence or special security forces (Sooka 1999).

\section{The TRC Report}

The CALS submission suggested that a gender approach was crucial for addressing the on-going suffering of women, implying a link between the past political violence and continuing violations, including domestic violence, which had already been documented by national and international human rights NGOs and CSVR. Human Rights Watch (1995) argued that a 'legacy of violence' associated with the apartheid policies has led to 'extremely high levels of violence throughout society, including domestic violence. By the time the TRC wrote its report, scholars had pointed out that in South Africa black men's experience of racism and social and economic deprivation often led to a sense of frustration and inferiority, which sometime manifested in violence against women (Mokwena 1991).

In response to these requests, the TRC's research department assigned Vanessa Barlosky, a researcher, to focus on gender. She drafted a report on 'gender and gross human rights violations,' which discussed and analysed a range of gender issues such as feminist theories on women and human rights, women's political struggle in South Africa and various gendered aspects of the past violence including not only physical abuses of rape and sexual torture but also social and economic discriminatory practices of apartheid. The draft report also examined the role of women in society and its effect on women's experience of human rights violations, explaining how the patriarchal structure of the society had relegated women to the 'private' or domestic sphere as opposed to the public sphere. It further provided an analysis showing that during a political and social crisis the public-private boundaries were often challenged and occasionally transformed. In such contexts, sexual violence can be used by those in power to destroy the new identity of women who became actively involved in politics and 


\section{Ayumi Kusafuka}

re-assert their inferiority and subordinate position (Barolsky 1997). The report further noted that the stigma and 'privatisation' of rape and sexual abuse, or dismissing such abuse as a 'private' issue, had led to 'unwillingness' to effectively prosecute gender-based violence (Barolsky 1997). Since it was written before April 1997, the draft report did not make much reference to the empirical findings of the TRC.

However, this apparently extensive gender research did not develop further from the draft stage and was very sparingly and fragmentally incorporated in the TRC's final report. Gender research was compromised due to constraints of time and resources on top of the limited scope of the Commission's mandate. Consequently, as has already been mentioned, gendered experiences were filtered through a narrow lens, which excluded a comprehensive analysis of gendered human rights abuse under apartheid and highlighted only certain incidents of gender-based violence. In addition, although some of the testimonies at the special women's hearings suggested the link between the political context and domestic violence (Special Women's Hearing 1997), the TRC never analysed the links between the political struggle of the past and the ongoing high rates of sexual and domestic violence. As such, the TRC final report considers gender 'in the narrowest possible terms' (Meintjes and Goldblatt 1999:1). Its chapter on women notes that:

The inclusion of a separate chapter on gender will be understood by some readers as sidelining, rather than mainstreaming, the issue. Women will again be seen as having been portrayed as a 'special interest group', rather than as 'normal' members of the society (TRC of SA 1998: 4.10.16).

The chapter provides a selection of women's testimonies from the special hearings and statistics based on the statements submitted to the TRC. It only makes brief references to the relationship between gender and political violence, for example, the economic discrimination faced by black women under apartheid (TRC of SA 1998: 4.10.19). Nonetheless, the report does critique the Commission's limitations in addressing gender issues and acknowledges that it would have to 'amend its understanding of its mandate and how it defined gross 
human rights violations' to 'integrate gender fully' in the TRC process. It notes that 'the Commission's relative neglect of the effects of the "ordinary" workings of apartheid has a gender bias' (TRC of SA 1998:10.17.19).

Ultimately the chapter on women, as well as the other chapters in Volume 4 which focus on the institutional and special hearings, is 'quite disconnected from the rest of the report with few points of intersection' (Fullard 2004). The wider TRC report also contains references to women's experiences but these are largely descriptive narratives rather than analysis (Goldblatt and Meintjes 1999). In Volume 5 it is noted that 'women too suffered direct gross violations of human rights, many of which were gender specific in their exploitative and humiliating nature' and a number of conclusions are made. These included that the state was responsible for 'the severe ill treatment of women in custody', that women 'were abused by the security forces in ways which specifically exploited their vulnerabilities as women' and that 'women in exile, particularly those in camps, were subjected to various forms of sexual abuse and harassment, including rape' (TRC of SA 1998:5.6.161).

In Volume 7 it is noted that '[d]espite the fact that rape formed part of the fabric of political conflict ... it was infrequently reported in HRV statements to the Commission' (TRC of SA 2003:7, p. 8). On the difference of experiences across gender, the report concludes that 'men were the most common victims of violations' (TRC of SA 2003:1.6. Appendix 2.23). They base this conclusion on the fact that 'six times as many men died as women and twice as many survivors of violations were men. Hence, although most people who told the Commission about violations were women, most of the testimonies were about men' (TRC of SA 1998:1.6. 23-24). However, it should be added that the report was meant to provide a reflection of the Commission's process and as such its confines were reflective of the wider limitations of the mandate and proceedings (Goldblatt and Meintjes 1999).

\section{Reparations}

Part of the Commission's mandate was to recommend reparation measures for victims of gross human rights violations identified by the Commission. The Act 


\section{Ayumi Kusafuka}

defines reparation as 'any form of compensation, ex gratia payment, restitution, rehabilitation or recognition' (Promotion of National Unity and Reconciliation Act No 34 of 1955: art.1(1)(xix)). The TRC adopted the following principles for reparation measures: redress, restitution, rehabilitation, restoration of dignity and reassurance of non-repetition. In line with these principles, the TRC made a number of recommendations to the South African government including: a) urgent interim reparations; b) individual reparation grants; c) symbolic reparations, including the establishment of community-based services and activities such as assistance in exhumations and burials; d) community rehabilitation, such as the provision of health and social services; and e) institutional reforms (TRC of SA 2003:5.5 ).

The input of women's groups to the design of the TRC's reparations recommendations was limited. In the early stage of the TRC, women activists were involved in making suggestions on reparations policy, for example through the CALS submission which recommended the TRC to take into account the unpaid labour of women in calculating financial compensation. The small working group of NGOs that met regularly from 1996 to 1997 to develop strategic responses to integrate gender issues into the TRC came up with a set of recommendations on a reparations policy, which was based on the assumption that women survivors may take years to feel ready to speak about their experiences and that mechanisms should be provided for taking statements long after the TRC had finished its work (Goldblatt and Meintjes 1997). At the consultative workshops the TRC held in 1997 to initially discuss formulating its reparations policy, women's groups and more sympathetic commissioners, including the Chairperson of the RRC, Commissioner Mkize, reiterated the importance of including women's experiences and perspectives in a reparations policy. This was evident in Commissioner Mkize's statement at the reparations policy workshop in Pietersburg in May 1997 as well as in the Oudtshoorn's Women Organisation's statement at a workshop in February 1997.

However, women's groups became less involved in forming the reparations policy by the time it was being prepared. As already noted, the women's movement was largely preoccupied with building a national gender policy and representation in the government as well as the pressing issue of contemporary 
issues of violence against women (Goldblatt 2006). While the RRC did consult through a number of workshops and meetings. attempts to integrate issues of gender in the reparations policies were largely left to victim support groups such as Khulumani and human rights NGOs, such as the CSVR (Goldblatt 2006).

Although women made up the majority of the RRC with four out of the five commissioners including the chairperson, women's special needs and interests were given limited consideration. Positively, the criteria for reparations eligibility adopted by the TRC allowed for both direct victims and their 'relatives and dependants - parents, spouses, children, and other dependants under the customary or legal duty of the victims' to receive reparations, including urgent interim reparation and individual reparation grants (TRC of SA 2003:5.5.33). In cases where the victim was deceased, the TRC applied the definition of relatives and dependants to the situation at the time of the victim's death (TRC of SA 2003:5.5.35). This inclusive approach enabled women relatives and dependants to claim reparations, as many women had participated in the TRC as 'secondary victims' (Goldblatt and Meintjes 1998b). It further extended the criteria to those relatives and dependants married under customary law, which was of great significance to many women (Goldblatt 2005).

Yet despite these specific criteria, the reparations recommendations were largely gender-blind and the eligibility criteria could not redress the underreporting of women's own experience of violence. The Commission adopted a closed list for reparations instead of an open one, which potentially could have allowed greater scope for victims to come forward and make claims for reparations. Both urgent interim and final reparation grants were available only to those who had been identified as 'victims' by the TRC, excluding those who had not made applications before the 'closed' deadline (Buford and Van der Merwe 2004). Moreover, the recommendations of the Commission did not specifically include any reparations and rehabilitation measures to address either the harms suffered by women as a category or specific gendered aspects of the past violence (Goldblatt 2005). As such, the reparations recommendations mirror the absence of centrality of gender in the TRC, combined with the lack of consciousness, expertise, and mobilisation around gender. 


\section{Reform, justice and public education}

The TRC's recommendations included institutional reforms in the judiciary, security forces, correctional services, and education, as well as public awarenessraising for 'the consolidation of democracy and the building of a culture of human rights' (TRC of SA 2003:5.8.1). In general, the recommendations were a set of very general and broad ideas that were put together without regard for both existing processes of transformation already initiated by the new government (Rauch 2004). References to gender were scattered and were made mostly with regard to measures intended to promote human rights in general. Those recommendations on gender or women's rights were minor adjustments or additions to the existing structures, instead of critical reforms addressing the gendered history of human rights violations. For example, recommendations included: the use of human rights curricula in 'formal education, specialised education and the training of law enforcement personnel', which 'must address issues of, amongst others, racism, gender discrimination, conflict resolution and the rights of children' (TRC of SA 2003:5.8.21para.21) and the 'fair' gender and racial representation in the judiciary, the 'Statutory Council', and the media.

Furthermore, the recommendations did not tackle the enabling and contributing causes of gendered human rights violations. The socio-economic vulnerability of women, particularly black women, remained unaddressed. Further, the TRC made no recommendation to end the impunity for violence against women as has occurred in subsequent commissions such as in Sierra Leone. Although the TRC called for the establishment of 'specialist prosecutorial task teams' to 'address serious endemic crimes', it did not include gender-based violence in the list of crimes (TRC of SA 2003:5.8.54). Similarly, the TRC did not specifically refer to rape or other gender-based violence, when it emphasised the importance of accountability for crimes 'where amnesty has not been sought or has been denied' and affirmed its willingness to cooperate with the prosecution through sharing information (Olckers 1996). 


\section{Conclusion}

The example of the South African TRC provides invaluable lessons for those developing future truth commissions as to how to better incorporate gender issues into the body's work. The South African case illustrates both the need for gender-friendly legislation when establishing a truth commission and, more critically, the necessity for a sustained and proactive relationship between a commission and the broad community of women's activists in order to place gender in the foreground of a commission's work. Failing to do this results in a missed opportunity to examine the structural, ideological, and systemic background of gender-based abuses. As a result, South Africa's Commission failed to unmask and address the links between structural and gendered violence that continue to plague the country.

Since gender and gendered experiences were filtered through a narrow prism due to the TRC's mandate, good intentions could not prevent the Commission's engagement being tangential. While the Commission's treatment of gender was initially shaped by confines of its legislation, its shortfalls were reinforced by the combination of constraints of time and resources, the non-existence of any systematic proactive gender strategy, and the lack of sustained involvement and interventions by the women's groups. As a consequence, gender was never incorporated in the TRC's work in a substantive way and the true history of South Africa's gendered past has yet to be recorded.

\section{Sources}

Barolsky, Vanessa 1997. Gender and gross human rights violations. Unpublished paper. Copy on file with author.

Buford, B. and H. van der Merwe 2004. Reparations in Southern Africa. Cahiers d'études africaines, 44 .

Buur, Lars 2002. Monumental historical memory: Managing truth in the everyday work of the South African Truth and Reconciliation Commission. In: Posel, D. and G. Simpson eds. Commissioning the past: Understanding South Africa's Truth and Reconciliation Commission. Johannesburg, Witwatersrand University Press.

Burton, M. 2000. Making Moral Judgments. In: Villa-Vicencio C. and W. Verwoerd eds. Looking back reaching forward: Reflections on the Truth and Reconciliation Commission of South Africa. Cape Town, University of Cape Town Press. 


\section{Ayumi Kusafuka}

Centre for the Study of Violence and Reconciliation (CSVR) and Khulumani Support Group 1998. Submission to the Truth and Reconciliation Commission: Survivors' perceptions of the Truth and Reconciliation Commission and suggestions for the Final Report. Report based on eleven reconciliation and rehabilitation workshops undertaken by the Centre for the Study of Violence and Reconciliation between 7 August 1997 and 1 February 1998. Available from: $<$ http://www.csvr.org.za/papers/papkhul.htm $>$.

Coalition of NGOs 1997. Submission to the Truth and Reconciliation Commission concerning the relevance of economic, social and cultural rights to the Commission's mandate.

Fullard, Madeleine 2004. Dis-placing race: The South African Truth and Reconciliation Commission (TRC) and interpretations of violence. Race and Citizenship in Transition Series (on-line version). Available from: <http://www.csvr.org.za/papers/paprctp3.htm>.

Goldblatt, Beth 2006. Evaluating the gender content of reparations: Lessons from South Africa. In: Rubio-Marin, R. ed. What happened to the women? Gender and reparations for human rights violations. New York, Social Science Research Council.

Goldblatt, Beth and Sheila Meintjes 1996. Gender and the Truth and Reconciliation Commission: A submission to the Truth and Reconciliation Commission.

Goldblatt, Beth and Sheila Meintjes 1997. Dealing with the aftermath - Sexual violence and the Truth and Reconciliation Commission. Agenda, 36.

Goldblatt, Beth and Sheila Meintjes 1998a. A gender perspective of violence during the struggle against apartheid. In: Bornman, E., R. van Eeden and M. Wentzel eds. Violence in South Africa: A variety of perspectives. Pretoria, Human Sciences Research Council.

Goldblatt, Beth and Sheila Meintjes 1998b. South African women demand the truth. In: Turshen, Meredeth and Clotilde Twagiramariya eds. What women do in wartime: Gender and conflict in Africa. London, Zed Books.

Goldblatt, Beth and Sheila Meintjes 1999. Women: A small part of one chapter in the history of South Africa. Paper presented to the Commissioning the Past Conference, University of the Witwatersrand, Johannesburg.

Hamber, Brandon and T. Mofokeng eds. 2001. From rhetoric to responsibility: Making reparations to the surviviors of past political violence in South Africa. Johannesburg, Centre for the Study of Violence and Reconciliation.

Hayner, P. 2001. Unspeakable truth: Confronting state terror and atrocity. New York, Routledge.

Health and Human Rights Projects (HHRP) 1997. Professional accountability in South Africa. Final submission to the Truth and Reconciliation Commission.

Human Rights Watch 1995. Violence against women in South Africa: The State response to domestic violence and rape. Available from: <http://www.hrw.org/en/reports/1995/11/01/ violence-against-women-south-africa>.

Interviews with Brandon Hamber, Nicky Rousseau, Graeme Simpson and Christelle Terreblance conducted by Ayumi Kusafuka on behalf of the ICTJ in August 2005. 
Krog, A. 2001. Locked into loss and silence: Testimonies of gender and violence at the South African Truth Commission. In: Moser, C. and F. Clark eds. Victims, perpetrators or actors?: Gender, armed conflict and political violence. London, Zed Books.

Madlala-Routledge, N. 1997. What price freedom? Women's testimony and the Natal Organisation of Women. Agenda, 34 .

Mokwena, S. 1991. The era of the jackrollers: Contextualising the rise of youth gangs in Soweto. Paper presented at the Centre for the Study of Violence and Reconciliation, Seminar No. 5.

Motsemme, N. 2004. The mute always speak: On women's silences at the Truth and Reconciliation. Current Sociology, 52 (5), pp. 909-932.

Olckers, Ilse 1996. Gender-neutral truth - A reality shamefully distorted. Agenda, 31.

Promotion of National Unity and Reconciliation Act No 34 of 1995. 26 July 1995.

Rauch, J. 2004. Police transformation and the South African TRC. In: Centre for the Study of Violence and Reconciliation, Race and citizenship in transition Series, 2004.

Simpson, Graeme 1992. Jack-asses and jackrollers: Rediscovering gender in understanding violence. Research report written for the Centre for the Study of Violence and Reconciliation, 1992.

Sooka, Y. 1999. Statement at the conference on The Aftermath: Women in post-war reconstruction, 20-22 July 1999, Johannesburg, South Africa. Available in Africa: Women in post-war reconstruction, The Africa Policy E-Journal, 30 September 1999.

TRC of SA (Truth and Reconciliation Commission of South Africa) 1997a. Special Hearing on Children and Youth held in Durban on 18 June 1997.

TRC of SA 1997b. Legal Hearing held in Johannesburg on 27 July 1997. Statement by Nadel Member.

TRC of SA 1997c. Special Women's Hearings held in Johannesburg on 29 July 1997.

TRC of SA 1997d. Legal Hearing held in Johannesburg on 27 October 1997. Statement by the then South African Minister of Justice, Dullah Omar.

TRC of SA 1997e. Business Sector Hearing held in Johannesburg on 12 November 1997.

TRC of SA 1998. Amnesty Hearing held in Johannesburg on 1 December 1998 for the cases of Machitje, Nkosi, Xaba and others.

TRC of SA 2003. Truth and Reconciliation Commission of South Africa Report. Kenwyn, Juta.

Zingxondo, Z. 1996. Woman tells of torture by police. Testimony in Beaufort West on 12 August 1996. South African Press Association (SAPA).

Van Zyl, M., J. de Gruchy, S. Lapinsky, S. Lewin and G. Reid 1999. The Aversion Project: Human rights abuses of gays and lesbians in the South African Defence Force by health workers during the apartheid era. Medical Research Council, Cape Town, October 1999. Available from: $<$ http://www.mrc.ac.za/healthsystems/aversion.pdf $>$. 
